\title{
Laboratory Evaluation of the Performance of Recycled Aggregate Concrete Containing Construction and Stone Factories Waste in Terms of Compressive and Tensile Strength
}

\author{
Ashkan Rah Anjam ${ }^{1}$ and Hadi Faghihmaleki $\mathbb{i D}^{2}$ \\ ${ }^{1}$ Faculty of Architectural Engineering, Allameh Dehkhoda Institute of Higher Education, Qazvin, Iran \\ ${ }^{2}$ Department of Civil Engineering, Ayandegan Institute of Higher Education, Tonekabon, Iran \\ Correspondence should be addressed to Hadi Faghihmaleki; h.faghihmaleki@gmail.com
}

Received 5 June 2020; Revised 22 July 2020; Accepted 3 August 2020; Published 20 August 2020

Guest Editor: Li-Tao Zhang

Copyright (c) 2020 Ashkan Rah Anjam and Hadi Faghihmaleki. This is an open access article distributed under the Creative Commons Attribution License, which permits unrestricted use, distribution, and reproduction in any medium, provided the original work is properly cited.

\begin{abstract}
Nowadays, the rapid growth of waste production and, especially, construction wastes has become one of the main problems in societies. In the world, reinforced concrete structures are destructed for different reasons. These destructions generate increasing values of waste. Furthermore, there are several stone factories in every region that produce a large volume of decorative construction stone wastes. This experimental study has investigated the effect of using recycled aggregates of construction and stone factory wastes in concrete production. Different tests were performed on concrete samples in fresh state (slump) and hardened concrete (compressive and tensile strength and modulus of elasticity). The optimal percentage for replacement of each of the recycled materials was determined based on comparing the results of laboratory tests. Finally, a proper mix design was proposed for both recycled aggregate samples, and a comprehensive report of the results was also provided.
\end{abstract}

\section{Introduction}

In the recent century, the rapid growth of waste production and, especially, construction wastes has become one of the main problems in societies. In the world, reinforced concrete structures are destructed for different reasons such as the finished useful life of the structure, the need to construct new buildings, and natural disasters such as earthquake, flood, and man-made disasters $[1,2]$. These destructions generate increasing values of waste. Furthermore, there are several stone factories in every region that annually produce hundreds of millions decorative stone wastes $[3,4]$. The first solution is to transfer and bury construction wastes out of cities. However, the increasing accumulation of these wastes will have negative long-term effects on the environment of suburbs and spread of water and air pollution in urban regions. The other solution is to recycle these materials and reuse them as alternative materials for natural ones $[5,6]$. This solution is more practicable in regions without natural aggregate mines. According to studies, urban solid wastes constitute $35 \%$ of total wastes in developed countries and $55 \%$ of total wastes in developing countries [7-9].

Recycled concrete aggregates are similar to crushed stones. Nevertheless, crushed concrete has various physical properties that are different from natural aggregates. In general, crushed concrete aggregates are more angled and have a less smooth surface than natural aggregates. Due to the unsmooth and angled surface of the aggregates compared to rounded, smooth, and dense aggregates, they require more water to form an efficient concrete [10].

$\mathrm{Wu}$ et al. [11] indicated that strength, hardness, and fracture energy of concrete, especially in high-strength concretes, depend on the type of aggregates. Also, low ratio of water-cement in high-strength concrete and the aggregate strength increase the concrete compressive strength. However, the effect of the aggregate type on 
compressive strength is not significant in normal strength concrete. In concretes with high compressive strength, the crack path may traverse through aggregates. So, aggregates play an important role in concrete strength.

Donza et al. [12] reported the result of investigating the effect of aggregates on compressive and tensile strength in high-resistance concrete. According to their findings, it was found that aggregate quality and strength is so effective in compressive and tensile strength of high-resistance concrete. Steel slags have shown the highest compressive and tensile strength in laboratory tests, while limestone materials have shown the lowest compressive and tensile strength.

In the research performed by Otoko in 2014 [13], in spite of using recycled brick aggregates with the highest quality in concrete production, the results suggested that the concrete produced by recycled brick aggregates has a lower quality than the concrete produced by natural stone aggregates. Furthermore, it was suggested to use the brick aggregate concrete in constructing the walls bearing low load or partition walls.

Ajdukiewiz and Kliszczewicz [14] investigated the effect of recycled aggregate on high-resistance concretes. In this research, mechanical properties of high-resistance recycled concrete have been compared to concretes produced by natural aggregates, and some tests were performed on 2-7year-old concretes with high or medium strength; the samples had been crushed at least 3 months before being reused.

The properties of RA obtained from various sources of C\&D [15] wastes are quite different. The brick-concrete structure which accounts for above $60 \%$ of the whole buildings is the most common building type in the towns. Table 1 gives the compositions of the $\mathrm{C} \& \mathrm{D}$ wastes in a typical city. Although the compositions of the construction wastes and demolition wastes are quite different, the waste concrete, waste bricks, and waste ceramics are the main compositions, which account for above $80 \%$ of the whole C\&D wastes. Thus, the recycled concrete aggregates, recycled brick aggregates, and recycled ceramic aggregates are the most common types of RA [16].

The present research is mainly aimed at achieving and introducing the most optimal conditions of using recycled construction and stone factory materials by proposing an appropriate mix design for concrete production based on the test results. The other research goals include evaluating and comparing the effect of using different values of alternative recycled aggregates on each of hardened concrete parameters such as mechanical properties and engineering properties (compressive and tensile strength), protection of nonrenewable environmental resources or those that are renewed in a long period of time, and decrease of construction wastes and environmental pollutions.

\section{Laboratory Programs}

In order to achieve reliable results, provide the possibility of replication of the tests, and increase their reliability, the materials property, the way of production of the studied samples, and the test stages should be explained in detail. First, properties of the materials used for producing the samples including sand, gravel, cement, recycled aggregates, and construction wastes are specified and the tests performed on each of them are explained separately. In the following, the test stages including naming the samples, water-cement ratio, processing of the samples, calibration devices, and primary mix designs (to choose the best mix design before starting the tests) were described briefly.

2.1. Properties of the Materials Used in the Tests. The materials used in the tests include the following.

2.1.1. Cement. All the tests have been performed by using sulfate-resisting Portland cement (Portland cement type II). All the properties of the used cement are corresponding to the due standards. The cement properties are presented in Table 2.

2.1.2. Water. The water used for concrete production was drinkable water supplied in Tehran.

2.1.3. Sand. In this study, crushed stone produced by factories was used as the sand sample. The aggregates properties included: maximum particles of $19 \mathrm{~mm}$, water absorption of $1.01 \%$, and special weight of $2650 \mathrm{~kg} / \mathrm{m}^{3}$. Table 3 presents the aggregate grading of the used sand.

2.1.4. Gravel. The used gravel was collected from river bed; the maximum size of aggregates was $4.75 \mathrm{~mm}$ with the water absorption of $5.28 \%$ and special weight of $2600 \mathrm{~kg} / \mathrm{m}^{3}$. Table 4 presents the gravel aggregate grading.

Fineness modulus is a single number obtained from the results of gravel aggregate grading test, and it is equal to the sum of cumulative percentages on screen no. 100 and the abovementioned screens divided by 100 . This number indicates the average size of the sand aggregates. A small value of fineness modulus shows that the gravel is finegrained, and a large value of fineness modulus shows that the gravel is coarse-grained. According to the ASTM C33 standard, fineness modulus of the gravel used for concrete production should range in 1.3-3.2 [17].

2.1.5. Recycled Aggregate. The used recycled aggregate contains crushed block, crushed brick, crushed tile and ceramics, and stone factory wastes. Table 5 presents the aggregate grading of the recycled aggregate.

2.2. Mix Design. Table 4 presents the mix design that is corresponding to ACI 211 by law [18]. It should be mentioned that five different mix designs have been studied in this research. Mix design no. 1 is the control sample in which no recycled materials have been used. In mix designs no. 2 and 3, construction wastes have been 
TABle 1: Compositions of C\&D wastes in a typical city [16].

\begin{tabular}{|c|c|c|c|c|c|}
\hline \multirow[b]{2}{*}{ Waste types } & \multicolumn{5}{|c|}{ Compositions (\%) } \\
\hline & Concrete & Brick & Gypsum & Steel & Wood \\
\hline Construction wastes & 42.9 & 38.3 & 1.1 & 6.5 & 11.2 \\
\hline Demolition wastes & 22.6 & 63.8 & 2.1 & 3.1 & 8.4 \\
\hline
\end{tabular}

TABle 2: The cement properties.

\begin{tabular}{lcc}
\hline Test & Result & Standard test no. \\
\hline Cement special weight & $15 / 3 \mathrm{~g} / \mathrm{cm}^{3}$ & ASTM-C188-89 \\
Final setting time of cement & After 3 hours & ASTM-C191-82 \\
Normal concentration of cement & 0.26 & ASTM-C187-86 \\
\hline
\end{tabular}

TABLE 3: Sand aggregate grading.

\begin{tabular}{lccc}
\hline Sand net weight $(\mathrm{g})$ & Container's empty weight $(\mathrm{g})$ & Full container weight $(\mathrm{g})$ & Screen no. \\
\hline 0 & 384.52 & 384.52 & $1 / 1 / 2$ \\
0 & 471.47 & 471.47 & 1 \\
169.4 & 445 & 614.40 & $3 / 4$ \\
530.17 & 462.02 & 992.19 & $1 / 2$ \\
264.3 & 408.85 & 655.15 & $3 / 8$ \\
101.98 & 445.13 & 547.11 & 4 \\
23.25 & 208.85 & 232.10 & The last container
\end{tabular}

TABLE 4: Gravel aggregate grading.

\begin{tabular}{lccc}
\hline Gravel net weight $(\mathrm{g})$ & Container's empty weight $(\mathrm{g})$ & Full container weight $(\mathrm{g})$ & Screen no. \\
\hline $586 / 55$ & $451 / 45$ & 1038 & 8 \\
$196 / 03$ & $316 / 16$ & $512 / 19$ & 16 \\
$91 / 24$ & $292 / 38$ & $363 / 62$ & 30 \\
$46 / 85$ & 288 & $334 / 85$ & 50 \\
$56 / 18$ & $254 / 82$ & 311 & 100 \\
$29 / 64$ & $255 / 93$ & $285 / 75$ & 200 \\
$4 / 87$ & $208 / 91$ & $213 / 08$ & The last container \\
\hline
\end{tabular}

TABLE 5: Recycled aggregate grading.

\begin{tabular}{lccc}
\hline Gravel net weight $(\mathrm{g})$ & Container's empty weight $(\mathrm{g})$ & Full container weight $(\mathrm{g})$ & Screen no. \\
\hline 0 & 384.52 & 384.52 & $1 / 1 / 2$ \\
$144 / 438$ & 471.47 & 615.908 & 1 \\
$423 / 67$ & 445 & 868.67 & $3 / 4$ \\
$433 / 19$ & 462.02 & 896.01 & $1 / 2$ \\
15 & 408.85 & 423.15 & $3 / 8$ \\
$2 / 59$ & 445.13 & 447.72 & 4 \\
$6 / 04$ & 208.85 & 214.89 & The last container \\
\hline
\end{tabular}

replaced, respectively, by $30 \%$ and $35 \%$. On the other hand, in mix designs no. 4 and 5, stone wastes have been replaced, respectively, by $30 \%$ and $35 \%$. Regarding the use of recycled materials and higher water absorption of such materials, we have used a specific and equal percentage of lubricant in all mix designs. It should be mentioned that the mix design studied in this research has been obtained based on the compressive strength of $300 \mathrm{~kg} / \mathrm{cm}^{2}, 9 \mathrm{~cm}$ slump, and the properties of the materials studied in this research.

Figure 1 presents some of the produced samples. The materials used in this (Figure 1) are according to the concrete mix proportions design of Table 6.

\subsection{Laboratory Tests}

2.3.1. Slump Test. According to ACI116-R90 by law, efficiency is defined as a property of concrete or just mixed mortar which determines the ease and integrity of mixing, casting in place, condensing the concrete, and processing its surface. According to the ASTM C125 standard, efficiency is a property determining the force required for moving the just mixed concrete with the minimum decrease of its integrity [19].

It should be mentioned that the slump test does not measure the concrete efficiency; rather, it describes its workability. According to the definition, workability is the 


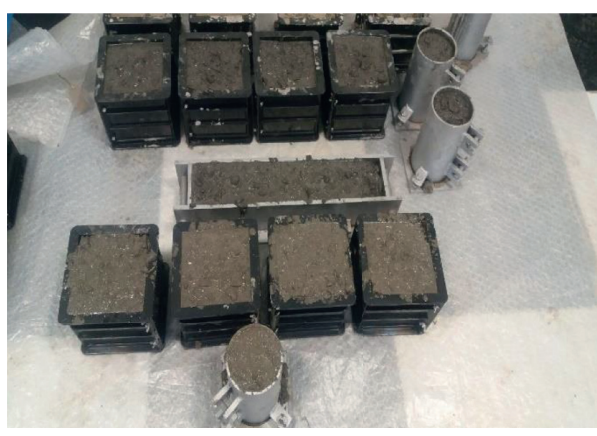

(a)

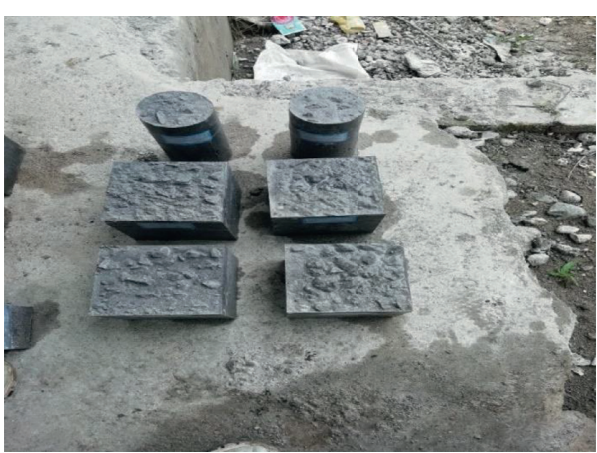

(b)

Figure 1: The concrete samples produced in this research.

TABLE 6: Concrete mix proportions design.

\begin{tabular}{lccccccc}
\hline $\begin{array}{l}\text { Lubricant } \\
\left(\mathrm{kg} / \mathrm{m}^{3}\right)\end{array}$ & Gravel $\left(\mathrm{kg} / \mathrm{m}^{3}\right)$ & Sand $\left(\mathrm{kg} / \mathrm{m}^{3}\right)$ & $\begin{array}{c}\text { Cement } \\
\left(\mathrm{kg} / \mathrm{m}^{3}\right)\end{array}$ & Water $\left(\mathrm{kg} / \mathrm{m}^{3}\right)$ & $\begin{array}{c}\text { Construction waste } \\
\left(\mathrm{kg} / \mathrm{m}^{3}\right)\end{array}$ & $\begin{array}{c}\text { Factory stone waste } \\
\left(\mathrm{kg} / \mathrm{m}^{3}\right)\end{array}$ & $\begin{array}{c}\text { Mix design no. } \\
3.07\end{array}$ \\
\hline 720.38 & 1214.9 & 376.32 & 138.85 & - & - & - \\
3.07 & 720.38 & 850.17 & 376.32 & 138.85 & 364.80 & - & 3 \\
3.07 & 720.38 & 789.50 & 376.32 & 138.85 & 425.47 & - & 364.8 \\
3.07 & 720.38 & $11 / 07$ & 376.32 & 138.85 & - & 425.47 \\
3.07 & 720.38 & $10 / 28$ & 376.32 & 138.85 & & 5 \\
\hline
\end{tabular}

relative fluidity or ability of the concrete to flow, and it is evaluated by the slump test based on the ASTM C143 standard [20]. Figure 2 presents the slump test of the samples.

2.3.2. Compressive and Tensile Strength Test. The compressive strength test is the most common test for evaluating concrete samples. Compressive strength of concrete samples can indicate the process of cement activities, quality of cement matrix of the concrete, and its relation with the aggregates. This test has a major role in structure design. The results can become affected by the changes in sample, sample size, the mold type, and processing conditions [21]. This test was performed on cubic samples of $15^{3}$ on the $7^{\text {th }}$ and $28^{\text {th }}$ days. The samples were taken out of the pond, and they were dried. Then, the tested cubic samples were put between the plates of the device on the side of the surface contacted with the cubic mold (Figure 3), and a vertical force was applied on the cubic sample with a constant velocity until rupture of the cubic sample; the highest force imposed at the time of rupture was recorded as the compressive strength of the sample.

For testing the tensile strength, the cylindrical sample is divided into two halves. The compressive force is applied on the lateral surface of the cylinder that is horizontally placed between the two plates of the test device. Applying the force continues until rupture of the sample, and the highest pressure applied at the time of rupture is recorded. On the $7^{\text {th }}$ and $28^{\text {th }}$ days, this test was performed on two cylindrical samples with the diameter of 15 and height of $30 \mathrm{~cm}$ according to the ASTM C496 standard [22].

\subsection{Analysis of the Tests}

2.4.1. Slump Test. Table 7 presents the results of the slump test on the samples.

As seen in Table 5, the results of slump test range from 7 to 10 , and this range is acceptable regarding the cement content and water-cement ratios. On the other hand, the comparison of the slump for the control sample and the recycled aggregate sample suggests that the slump is decreased in the samples containing recycled aggregate. So, it can be concluded that, in samples containing recycled aggregates, the water absorption percent is higher due to the existence of different materials.

2.4.2. Compressive Strength Test. As stated before, a compressive strength test was performed on 3 cubic samples of $15^{3}$ for every mix design on the $7^{\text {th }}$ and $28^{\text {th }}$ days. The final compressive strength was obtained by calculating the mean values of compressive strength. Table 8 presents the mean compressive strength of the samples.

As seen in Table 6, the final compressive strength of the control sample is higher than the compressive strength of samples contacting recycled aggregate, as predicted before. However, the sample containing the recycled aggregate of stone factory wastes has a higher compressive strength than the sample containing recycled aggregate of construction wastes. On the other hand, the most optimal percentage of recycled aggregate replacement is $30 \%$. 


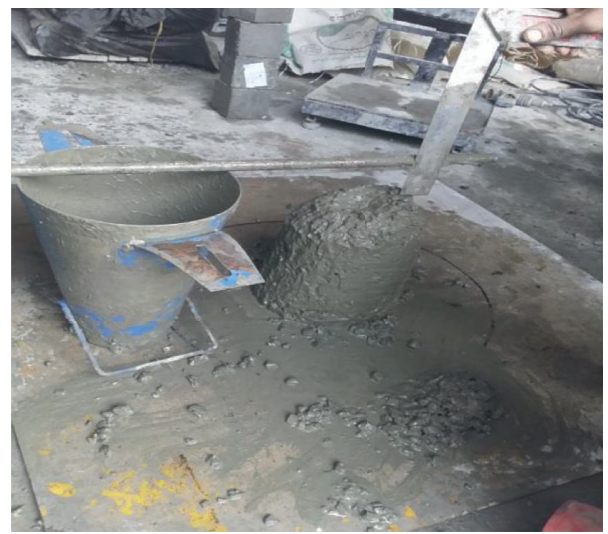

Figure 2: Slump test on the samples.

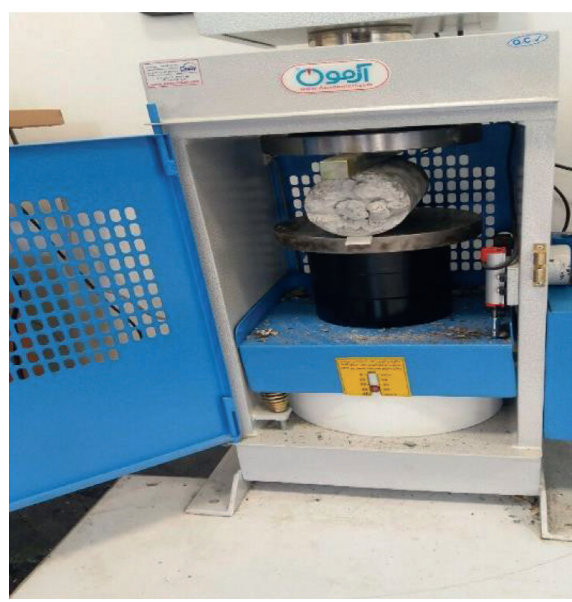

(a)

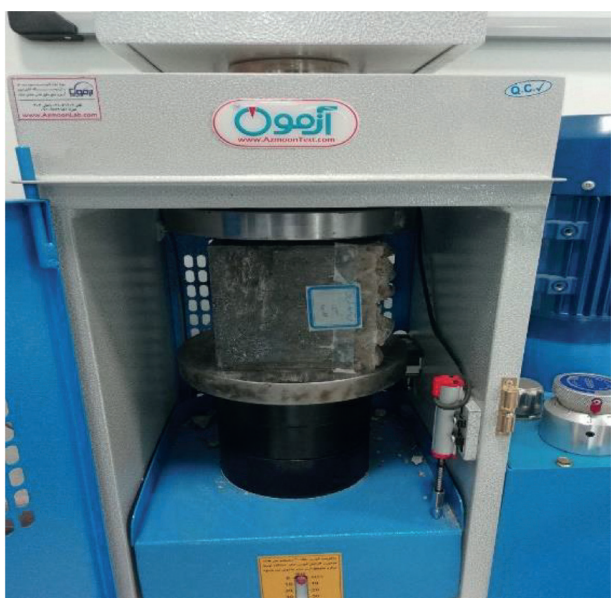

(b)

FIgURE 3: Concrete sample test.

TABLE 7: The results of the slump test.

\begin{tabular}{lccc}
\hline Test & $\begin{array}{c}\text { Control sample } \\
(\mathrm{cm})\end{array}$ & $\begin{array}{c}\text { Recycled aggregates containing } 30 \% \text { of construction } \\
\text { wastes }(\mathrm{cm})\end{array}$ & $\begin{array}{c}\text { Recycled aggregate with } 30 \% \text { of stone factory } \\
\text { wastes }(\mathrm{cm})\end{array}$ \\
\hline Slump & 9.6 & 6.7 & 7.9 \\
\hline
\end{tabular}

2.4.3. Tensile Strength Test. Tensile strength of concrete is an important parameter involved in calculating the concrete crack and determining the minimum number of the required rebar. In this study, the indirect (Brazilian) tensile test was performed for measuring the concrete tensile strength on the $28^{\text {th }}$ day. Table 9 presents the mean tensile strength of the samples. According to the results of tensile strength test, only the samples with a $30 \%$ content of recycled aggregate have been studied in this test.

The results of tensile strength test (Table 9) suggest that the recycled aggregates of construction wastes have a lower tensile strength than the recycled aggregates of stone factory wastes.

2.4.4. Stress-Strain Diagrams. Figures 4-6 present the stressstrain diagrams. Any change or increase of strength leads to increased elasticity modulus. Since the elasticity modulus of the concrete is affected by elasticity modulus of its constituents such as aggregates, increase of elasticity modulus with the change in aggregate type which leads to decreased porosity of cement paste and increased compressive strength is something obvious. Meanwhile, the higher is the strength, the more brittle the concrete will be [23].

\section{Conclusions}

This research has compared the concrete containing recycled aggregate of construction wastes and concrete containing recycled aggregate of stone factory wastes in terms of compressive and tensile strength. For this purpose, the slump test, compressive and tensile strength tests, and elasticity modulus test were performed on the concrete samples; the results are as follows: 
TABLE 8: The mean compressive strength of the samples.

\begin{tabular}{lcc}
\hline 28 -day compressive strength $(\mathrm{MPa})$ & 7-day compressive strength $(\mathrm{MPa})$ & Mix design no. \\
\hline 32.83 & 17.44 & 1 \\
29.30 & 19.99 & 2 \\
24.01 & 17.83 & 3 \\
31.95 & 15.00 & 4 \\
30.57 & 16.66 & 5 \\
\hline
\end{tabular}

TABle 9: The mean tensile strength of the samples.

\begin{tabular}{lcc}
\hline 28 -day compressive strength $\left(\mathrm{kg} / \mathrm{cm}^{2}\right)$ & 7-day compressive strength $\left(\mathrm{kg} / \mathrm{cm}^{2}\right)$ & Mix design no. \\
\hline 52.3 & 18.2 & 1 \\
35.5 & 15.6 & 2 \\
45.1 & 16.4 & 4 \\
\hline
\end{tabular}

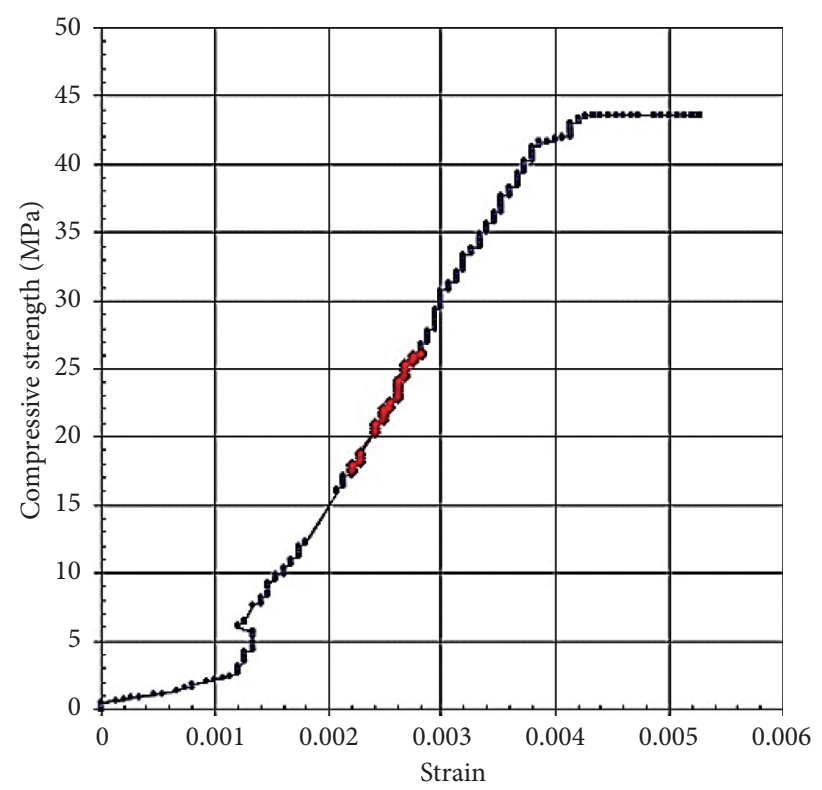

FIGURE 4: Stress-strain diagram of the control sample.

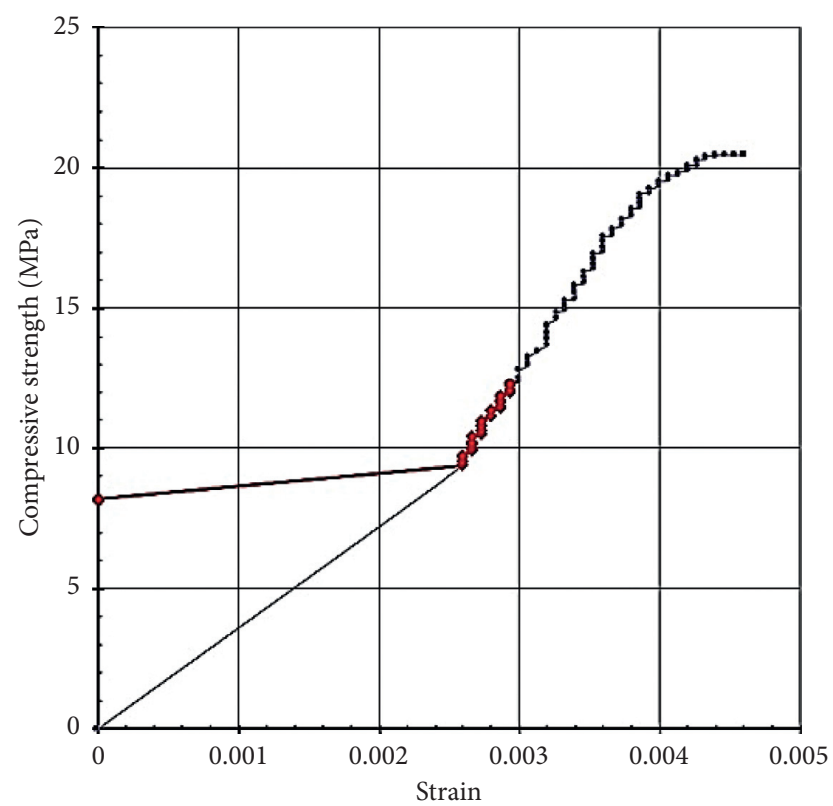

FIgURE 5: Stress-strain diagram of the recycled aggregate of stone factory wastes (30\% replacement). 


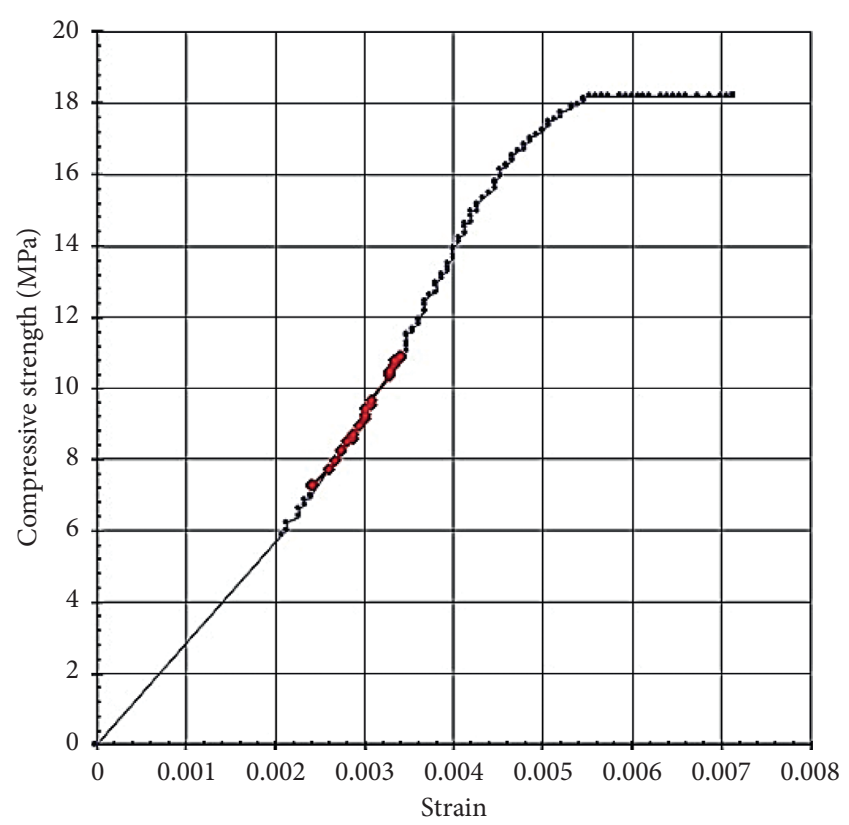

FIgURE 6: Stress-strain diagram of the recycled aggregate of construction wastes (30\% replacement).

(1) Concrete containing stone factory wastes have a higher slump than concrete containing recycled aggregate of construction wastes. In general, the samples containing recycled aggregate had a lower slump than the control group.

(2) The final compressive strength of the concrete containing recycled aggregates of stone factory wastes is about $9 \%$ more than the concrete containing recycled aggregate of construction wastes. Anyway, in this research, the optimal percentage of replacing aggregate for materials has been reported as $30 \%$.

(3) As the results of compressive strength, recycled aggregates of stone factory wastes have a higher tensile strength than recycled aggregates of construction wastes (about 27\%).

(4) The mean elasticity modulus has been obtained as 20.44 for the concrete containing stone factory wastes and 18.18 for the concrete containing construction waste recycled aggregates; so, elasticity modulus is higher for the concrete containing stone factory wastes.

\section{Data Availability}

The data used to support the findings of this study are available from the corresponding author upon request.

\section{Conflicts of Interest}

The authors declare that there are no conflicts of interest in this paper.

\section{References}

[1] H. X. Qian, Y. C. Zhi, G. Xiao, L. Qiang, and L. L. Xiao, "Damage to recycled concrete with different aggregate substitution rates from the coupled action of freeze-thaw cycles and sulfate attack," Construction and Building Materials, vol. 221, pp. 74-83, 2019.

[2] H. Faghihmaleki, E. K. Najafi, and A. H. Aini, "Seismic rehabilitation effect in a steel moment frame subjected to tow critical loads," International Journal of Structural Integrity, vol. 8, no. 1, pp. 1-11, 2017.

[3] S. Aydin, H. Yazici, and Y. Y. Mert, "Effect of aggregate type on mechanical properties of reactive powder concrete," $A C I$ Materials Journal, vol. 107, no. 5, pp. 441-449, 2010.

[4] A. Neville, Properties of Concrete, Longman Publications, London, UK, 1996.

[5] M. A. Caldarone, High Strength Concrete A Practical Guide, Taylor \& Francis Publication, Abingdon, UK, 2009.

[6] G. Abdollahzadeh and H. Faghihmaleki, "Proposal of a probabilistic assessment of structural collapse concomitantly subject to earthquake and gas explosion," Frontiers of Structural and Civil Engineering, vol. 12, no. 3, pp. 425-437, 2018.

[7] A. Ayodele, B. F. Amor, B. Jean-François, C. Camille, and G. Denis, "Experimental and micromechanical investigation on the mechanical and durability properties of recycled aggregates concrete," Cement and Concrete Research, vol. 126, Article ID 105900, 2019.

[8] C. Yuliang, C. Zongping, X. Jinjun, M. L. Eric, and W. Bo, "Performance evaluation of recycled aggregate concrete under multiaxial compression," Construction and Building Materials, vol. 229, Article ID 116935, 2019.

[9] S. W. Tabsh and A. S. Abdelfatah, "Influence of recycled concrete aggregates on strength properties of concrete," Construction and Building Materials, vol. 23, no. 2, pp. 1163-1167, 2009.

[10] F. Pacheco-Torgal and Y. Ding, Handbook of Recycled Concrete and Demolition Waste, Elsevier, Amsterdam, Netherlands, 2013.

[11] K.-R. Wu, B. Chen, W. Yao, and D. Zhang, "Effect of coarse aggregate type on mechanical properties of high-performance concrete," Cement and Concrete Research, vol. 31, no. 10, pp. 1421-1425, 2001.

[12] H. Donza, O. Cabrera, and E. F. Irassar, "High-strength concrete with different fine aggregate," Cement and Concrete Research, vol. 32, no. 11, pp. 1755-1761, 2002.

[13] G. R. Otoko, "Recyclcling of products of bricks plants in Nigeria: rivers state university of science and technology, port harcourt," European International Journal of Science and Technology, vol. 3, no. 1, pp. 21-30, 2014.

[14] A. Ajdukiewiz and A. kliszczewicz, "Influence of recycled aggregates on mechanical properties of HS/HPC," Cement and Concrete Composites, vol. 24, no. 2, pp. 269-279, 2002.

[15] J. Li, Y. Chen, Z. Chen, and Q. Tan, "Experimental study on mechanical properties of recycled concrete in tri-axial compression," Concrete, vol. 304, no. 2, pp. 65-68, 2015, in Chinese.

[16] Z. Ma, Q. Tang, D. Yang, and G. Ba, "Durability studies on the recycled aggregate concrete in China over the past decade: a review," Advances in Civil Engineering, vol. 2019, 19 pages, Article ID 4073130, 2019.

[17] W. Yonggui, H. Peter, N. Haicheng, and F. Yuhui, "A new method to improve the properties of recycled aggregate concrete: composite addition of basalt fiber and nano-silica," 
Journal of Cleaner Production, vol. 236, Article ID 117602, 2019.

[18] E. Sharifi, S. J. Sadjadi, M. R. M. Aliha, and A. Moniri, "Optimization of high-strength self-consolidating concrete mix design using an improved taguchi optimization method," Construction and Building Materials, vol. 236, Article ID 117547, 2020.

[19] H. Faghihmaleki, F. Nejati, and H. Masoumi, "In vitro evaluation of additives allowed for high strength concrete (HSC) and foam concrete," Pamukkale University Journal of Engineering Sciences, vol. 23, no. 3, pp. 177-183, 2017.

[20] R. Rumman, M. S. Bari, T. Manzur, M. R. Kamal, and M. A. Noor, "A durable concrete mix design approach using combined aggregate gradation bands and rice husk ash based blended cement," Journal of Building Engineering, vol. 30, Article ID 101303, 2020.

[21] K. Rashid, S. Farooq, A. Mahmood, S. Iftikhar, and A. Ahmad, "Moving towards resource conservation by automated prioritization of concrete mix design," Construction and Building Materials, vol. 236, Article ID 117586, 2020.

[22] A. Habibi and J. Ghomashi, "Development of an optimum mix design method for self-compacting concrete based on experimental results," Construction and Building Materials, vol. 168, pp. 113-123, 2018.

[23] C. S. Thunuguntla and T. D. Gunneswara Rao, "Effect of mix design parameters on mechanical and durability properties of alkali activated slag concrete," Construction and Building Materials, vol. 193, pp. 173-188, 2018. 